\title{
Direct-acting Antivirals and Host-targeting Agents against the Hepatitis A Virus
}

\author{
Tatsuo Kanda*, Shingo Nakamoto, Shuang Wu, Masato Nakamura, Xia Jiang, Yuki Haga, \\ Reina Sasaki and Osamu Yokosuka
}

\author{
Department of Gastroenterology and Nephrology, Chiba University, Graduate School of Medicine, Inohana, \\ Chuo-ku, Chiba, Japan
}

\begin{abstract}
Hepatitis A virus (HAV) infection is a major cause of acute hepatitis and occasionally leads to acute liver failure in both developing and developed countries. Although effective vaccines for HAV are available, the development of new antivirals against HAV may be important for the control of HAV infection in developed countries where no universal vaccination program against HAV exists, such as Japan. There are two forms of antiviral agents against HAV: direct-acting antivirals (DAAs) and host-targeting agents (HTAs). Studies using small interfering ribonucleic acid (siRNA) have suggested that the HAV internal ribosomal entry site (IRES) is an attractive target for the control of HAV replication and infection. Among the HTAs, amantadine and interferon-lambda 1 (IL-29) inhibit HAV IRES-mediated translation and HAV replication. Janus kinase (JAK) inhibitors inhibit La protein expression, HAV IRES activity, and HAV replication. Based on this review, both DAAs and HTAs may be needed to control effectively HAV infection, and their use should continue to be explored. (c) 2015 The Second Affiliated Hospital of Chongqing Medical University. Published by XIA \& HE Publishing Ltd. All rights reserved.
\end{abstract}

\section{Introduction}

Hepatitis A virus (HAV) infections remain a major cause of acute hepatitis and occasionally lead to acute liver failure (ALF). ${ }^{1}$ Liver transplants are occasionally used in the treatment of HAV-associated ALF. ${ }^{2}$ Acute kidney injury, ${ }^{3,4}$ hemophagocytic syndrome, ${ }^{5}$ and pure red cell aplasia ${ }^{6}$ have

Keywords: Amantadine; DAA; HAV; HTA; La protein; Drug overview.

Abbreviations: ALF, acute liver failure; DAAs, direct-acting antivirals; DNA, deoxyribonucleic acid; dsRNA, double-stranded RNA; eIF, eukaryotic initiation factor; FMK, fluoromethyl ketone; FRhK, fetal rhesus monkey kidney; GAPDH, glyceraldehyde-3-phosphate dehydrogenase; HAV, hepatitis A virus; HCV, hepatitis $C$ virus; HIV, human immunodeficiency virus; HLA, human leukocyte antigen; HTAs, host-targeting agents; IL, interferon-lambda; IRES, internal ribosomal entry site; JAK, janus kinase; PCBP2/hnRNP-E2, poly(C) binding protein 2; PTB/hnRNPI, polypyrimidine tract-binding protein; RNA, ribonucleic acid; RNAi, RNA interference; shRNAs, short hairpin RNAs; siRNAs, small interfering RNAs; STAT3, signal transducer and activator of transcription 3, UTR, untranslated region; VP, viral protein.

Received: 13 May 2015; Revised: 10 June 2015; Accepted: 11 June 2015

DOI: $10.14218 / \mathrm{JCTH} .2015 .00016$.

* Correspondence to: Tatsuo Kanda, Department of Gastroenterology and Nephrology, Chiba University, Graduate School of Medicine, 1-8-1 Inohana, Chuo-ku, Chiba 260-8670, Japan. Tel: +81-43-226-2086, Fax: +81-43-226-2088, E-mail: kandat-cib@umin.ac.jp been associated with HAV infection. HAV is usually transmitted by the fecal-oral route, and it was found that the prevalence of HAV infection decreased with the improvement of sanitation conditions in developed countries. ${ }^{7}$

Despite the successful results of childhood hepatitis $A$ vaccination programs in the United States, the mean age at death among decedents with HAV infection increased to 76.2 years in 2011.7 HAV-related mortality declined, however, suggesting that older patients are more susceptible to HAV infection and more severely affected. 7,8

In Japan, no universal vaccination program against HAV exists, and only $14 \%$ of indigenous Japanese people have received anti-HAV vaccinations. ${ }^{9}$ The positive rate of anti-HAV in patients under 30 years $(0-7 \%)$ was found to be lower than those over 50 years (33\%) in the indigenous Japanese population. ${ }^{9}$ Therefore, the possibility of an outbreak of an HAV epidemic exists. ${ }^{10,11}$ A similar situation exists in South Korea. ${ }^{12}$ Although there are safe and effective vaccines against $H A V$, it is also important to discover new host cell targets and to develop potential drugs for the treatment of HAV. ${ }^{13-15}$

HAV internal ribosomal entry-site (IRES)-mediated translation and replication

HAV is a member of the Hepatovirus genus of the Picornaviridae family. There are at least six genotypes of HAV, and three of them (I to III) are of human origin. ${ }^{16,17} \mathrm{HAV}$ is a positive single-stranded, nonenveloped ribonucleic acid (RNA) virus of $\sim 7,500$ bases in length. The HAV genome codes one open reading frame that encodes structural (viral protein (VP)4, VP2, VP3, and VP1) and nonstructural proteins (2A, 2B, 2C, $3 A, 3 B, 3 C$, and $3 D$ ) and is flanked by a $5^{\prime}$ untranslated region (UTR) and a $3^{\prime}$ UTR. The HAV genome is translated into a single polyprotein in a cap-independent manner, i.e. HAV exhibits IRES-mediated translation. Subsequently, the single HAV polyprotein is proteolytically processed by protease $3 \mathrm{C}$ and cellular protease(s) into several functional and mature proteins. ${ }^{13,18,19}$ HAV IRES-mediated translation and HAV RNA replication are important for HAV virion formation (Fig. 1). HAV 3D is the RNA-dependent RNA polymerase. ${ }^{18,19}$ In fact, HAV IRES and HAV $3 \mathrm{C}$ are attractive targets of antiviral drugs against HAV.

\section{Antivirals against HAV (Table 1, Fig. 2)}

Two forms of antiviral agents against HAV exist: direct-acting antivirals (DAAs) and host-targeting agents (HTAs). DAAs 


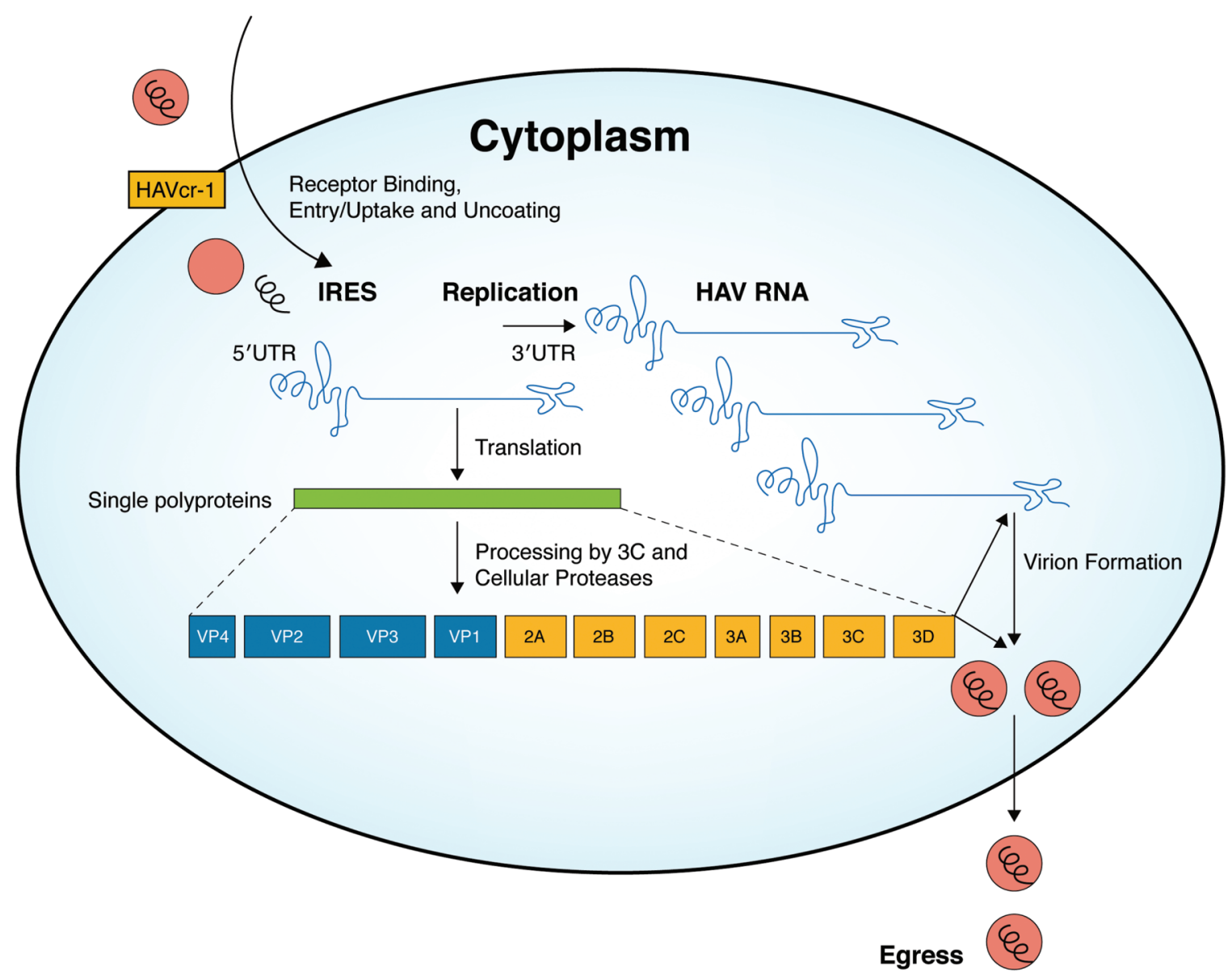

Fig. 1. The life cycle of the hepatitis A virus (HAV). HAVcr-1, HAV cellular receptor 1; IRES, internal ribosomal entry-site; UTR, untranslated region.

specifically target HAV and include protease inhibitors, a polymerase inhibitor, and IRES inhibitors. DAAs have none of the adverse events associated with interferon, such as flulike syndrome, hematologic effects, or depression. However, studies of human immunodeficiency virus (HIV) and hepatitis $\mathrm{C}$ virus (HCV) suggest that several DAAs exhibit genotypespecific antiviral activities with low genetic barriers to resistance. ${ }^{20-22}$ HTAs have high genetic barriers to resistance and exhibit pan-genotypic antiviral activities. HTAs have mechanisms of action that are complementary to those of DAAs, and HTAs typically act in a synergistic manner with DAAs. ${ }^{23}$ In order to effectively control HAV, it is important to develop both DAAs and HTAs.

\section{DAAs against HAV}

\section{HAV 3 C protease inhibitors}

HAV 3 C proteinases play an important role in the processing of the HAV polyprotein. Inhibitors of HAV $3 \mathrm{C}$ can result in the suppression of HAV replication, and there are several reports available regarding inhibition of HAV $3 C .{ }^{24-34}$ The binding of the peptide aldehyde Ac-Leu-Ala-Ala- $(N, N$ dimethyl-glutaminal) to the HAV $3 \mathrm{C}$ proteinase leads to
Table 1. Effective antiviral agents against hepatitis A virus (HAV)

\begin{tabular}{|c|c|}
\hline $\begin{array}{l}\text { Direct-acting antivirals } \\
\text { (DAAs) }\end{array}$ & Host-targeting agents (HTAs) \\
\hline $\begin{array}{l}\text { HAV } 3 \text { C cysteine protease } \\
\text { inhibitors }\end{array}$ & Broad-target HTAs \\
\hline- & Interferon-alpha ${ }^{45,46}$ \\
\hline $\begin{array}{l}\text { Small interfering RNAs } \\
\text { against } \mathrm{HAV}^{18,40,42}\end{array}$ & Interferon-gamma ${ }^{52}$ \\
\hline Targets: $2 \mathrm{C}, 3 \mathrm{C}$ and IRES & $\begin{array}{l}\text { Interferon-lambda } 1 \\
(\text { IL-29) }\end{array}$ \\
\hline- & Ribavirin ${ }^{58-60}$ \\
\hline- & Amantadine ${ }^{58-64}$ \\
\hline- & $\begin{array}{l}\text { More precisely targeted } \\
\text { HTAs }\end{array}$ \\
\hline- & $\begin{array}{l}\text { Agents against key host } \\
\text { enzymes }{ }^{14}\end{array}$ \\
\hline- & $\begin{array}{l}\text { Agents against key cellular } \\
\text { factors }\end{array}$ \\
\hline- & Target: La*15,65 \\
\hline
\end{tabular}

\footnotetext{
* Suppression of HAV internal ribosomal entry-site (IRES).
} 


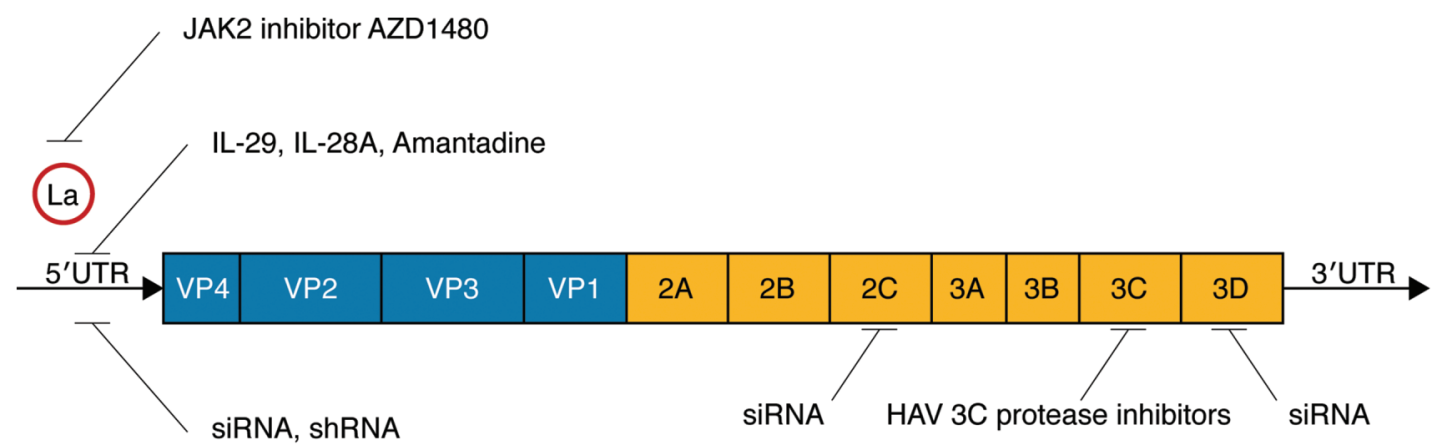

Fig. 2. Structure of the hepatitis A virus (HAV) and targets of antiviral agents. UTR, untranslated region.

reversible and slow-binding inhibition of HAV $3 C .{ }^{24} \mathrm{~A}$ peptidyl monofluoromethyl ketone (peptidyl-FMK) inhibitor analogous to the peptide aldehyde has the ability to suppress HAV polyprotein processing and HAV replication. ${ }^{25} \mathrm{HAV}$ replication is reduced 25 -fold in the presence of $5 \mu \mathrm{M}$ peptidyl-FMK in subclone 11-1 fetal rhesus monkey kidney cells (FRhK-4-cells) at day 1 postinfection. ${ }^{25,35}$ Beta-lactones also represent a new class of cysteine proteinase inhibitors that act on HAV $3 \mathrm{C}$ cysteine proteinases. ${ }^{28,31}$ Blaum et al. ${ }^{34}$ identified the hexanucleotide 5'-GGGGGT-3' (G(5)T) as an HAV 3C protease inhibitor and reported that the sequence-specific small nucleic acid-protein interaction mediated by this hexanucleotide may suppress HAV replication. Thus, an HAV $3 \mathrm{C}$ protease inhibitor is an attractive DAA.

\section{HAV-specific small interfering RNAs (siRNAs)}

In general, siRNAs can specifically knockdown target genes and have significantly affected biological and pharmacological research. ${ }^{36}$ Gene knockdown is achieved using $\sim 21$ nucleotide double-stranded RNA (dsRNA) intermediates that are known as siRNAs, and they do not activate the interferon signaling pathway. Such siRNAs prevent a target gene from producing its functional protein. ${ }^{37}$ RNA interference (RNAi) may effectively treat viral infection with or without traditional antiviral therapies, although delivery of siRNAs to target cells is difficult. ${ }^{38,39}$

Initially, we made and examined the effects of several SiRNAs that targeted HAV nonstructural protein-coding regions related to HAV replicon replication. ${ }^{18,40}$ Our studies revealed that siRNAs against the HAV 2C- and 3D-coding regions inhibited HAV $2 \mathrm{C}$ and HAV $3 \mathrm{D}$ expression and that the combination of 2C-siRNAs and 3D-siRNAs strongly inhibited HAV replication. ${ }^{40}$ Although consecutive siRNA applications select mutants that either preexist as quasispecies of the HAV genome or are generated during genome replication in HAV infection, consecutive siRNA transfections targeting multiple sequences in the HAV genome may result in a more efficient and sustained silencing effect than a single transfection. ${ }^{41}$

\section{HAV-specific SIRNAs suppress HAV IRES-mediated translation and $\mathrm{HAV}$ replication}

We showed that various siRNAs that target the HAV IRES suppressed HAV IRES-mediated translation and HAV replication. ${ }^{42}$ RNase III (endoribonuclease)-prepared siRNAs (esiRNAs) that are targeted to various domains of the HAV IRES efficiently suppressed replication-competent HAV replicon replication to $42 \%(0.5 \mu \mathrm{g} / \mathrm{mL}$ esiRNA) and $12 \%$ $(1.0 \mu \mathrm{g} / \mathrm{mL}$ esiRNA) of the control level at $48 \mathrm{~h}$ post-infection.

In a previous study, ${ }^{42}$ we made several vector-derived short hairpin RNAs (shRNAs) that targeted HAV IRES and examined their effects on HAV replicon replication. Although several shRNAs that targeted the loop regions of stem-loop structures of the HAV IRES were made, the shRNAs that targeted the HAV IRES domains IIIc and V were found to efficiently suppress genome translation and replication. This study suggested that the HAV IRES domains might serve as attractive targets for suppression of HAV replication and HAV infection. Thus, siRNA against HAV nonstructural protein coding region and HAV IRES is an attractive DAA, but there are difficulties in the delivery methods of siRNAs.

\section{HTAs against HAV}

\section{Type I interferon}

The eradication of HAV from human hepatocytes is associated with interferon systems. ${ }^{43,44}$ It has been reported that interferon-alpha exhibits antiviral activity against HAV replication in the human hepatoma cell line PLC/PRF/5. ${ }^{45,46}$ Interferonalpha suppresses HAV replicon replication and HAV replication, although interferon-alpha seems to have no additive effect on the suppression of HAV IRES-mediated translation by amantadine. ${ }^{47}$ Interferon was found to be clinically effective for the suppression of HAV infection in some cases, ${ }^{48,49}$ but it is contraindicated for severe HAV infections, including fulminant hepatitis, due to its adverse effects or its impairment of the interferon systems. ${ }^{50,51}$

\section{Other types of interferons}

Interferon-gamma is produced upon HAV stimulation by HAVspecific human leukocyte antigen (HLA)-dependent T8+ (cytotoxic) T-lymphocytes and plays a role in the eradication of HAV infection. ${ }^{52}$ Recombinant interferon-gamma exhibits antiviral effects against persistent HAV infection in human fibroblasts. ${ }^{52}$

It was recently reported that interferons-lambda [i.e., interferon-lambda 1 (IL-29), interferon-lambda 2 (IL-28A), and interferon-lambda 3 (IL-28B)] can inhibit HCV IRESmediated translation and that IL-29 and IL-28A but not IL-28B can inhibit HAV IRES-mediated translation. ${ }^{53}$ In the same study, $100 \mathrm{ng} / \mathrm{mL}$ of IL-29 led to a $23 \%$ inhibition of HAV subgenomic replication, and $250 \mathrm{ng} / \mathrm{mL}$ and $500 \mathrm{ng} / \mathrm{mL}$ of IL-29 tended to inhibit HAV propagation without cell 
damage. Because interferons-lambda use a receptor complex that is different from that of interferon-alpha and the majority of bone marrow-derived cells and nerve cells do not express the receptors for interferons-lambda, interferon-lambda resulted in fewer adverse events, such as the hematological cytotoxicities or depression, compared with interferonalpha. ${ }^{54}$ Therefore, interferons-lambda may be useful for severe conditions resulting from HAV infection. Further studies are needed.

\section{Ribavirin}

Ribavirin (1-beta-D-ribofuranosyl-1,2,4-triazole-3-carboxamide) is a broad-spectrum synthetic guanosine analog that acts against deoxyribonucleic acid (DNA) and RNA viruses. ${ }^{55-57}$ At $100 \mu \mathrm{M}$, ribavirin moderately inhibited HAV propagation. ${ }^{58}$ The effects of ribavirin on HAV replication may be nonspecific, ${ }^{58-60}$ and ribavirin has no effect on HAV IRESmediated translation. ${ }^{61}$

\section{Amantadine}

Amantadine is a tricyclic symmetric amine and is also a broadspectrum antiviral that acts against influenza $A$ viruses. ${ }^{61}$ Several groups have reported the effects of amantadine on the growth of HAV in cell culture models. ${ }^{58,59,62}$ Amantadine inhibited viral antigen synthesis when added to cells after the attachment step, ${ }^{62}$ suggesting that amantadine acts during or after the HAV entry pathway. ${ }^{62}$ Amantadine also inhibited HAV IRES-mediated translation and HAV replication. ${ }^{61}$ Amantadine can inhibit clinical isolate-derived HAV IRES-mediated translation, ${ }^{63}$ although the effects of amantadine may be strain-dependent. ${ }^{64}$ The influence of HAV genotypes and sequence variations on the effects of amantadine should be explored. ${ }^{10,11,17}$ The combinations of amantadine with interferon-alpha or IL-29 resulted in stronger inhibitory effects on HAV replication compared with amantadine alone. ${ }^{47,53}$ Broad-target HTAs, such as interferon, ribavirin and amantadine, may suppress HAV replication in certain HAV patients.

\section{Agents against key host enzymes and cellular factors}

The key host enzymes and cellular factors that are required for the viral lifecycle are targets of antiviral therapies. ${ }^{65}$ Several cellular proteins, such as autoantigen $\mathrm{La}^{66}$ glyceraldehyde-3phosphate dehydrogenase (GAPDH) ${ }^{67,68}$ polypyrimidine tractbinding protein (PTB/hnRNPI), ${ }^{68-70}$ poly(C) binding protein 2 (PCBP2/hnRNP-E2), ${ }^{71}$ polyadenylate-binding protein-1 $(\mathrm{PABP}){ }^{72}$ eukaryotic translation initiation factor $4 \mathrm{E}$ (eIF4E) ${ }^{73}$ and eukaryotic translation initiation factor $4 \mathrm{G}$ (eIF4G), ${ }^{72,74,75}$ interact with HAV IRES RNA. These proteins might be associated with HAV replication. SiRNAs against La strongly inhibited HAV IRES activities and HAV subgenomic replication. ${ }^{65}$ The janus kinase (JAK) inhibitors SD-1029 and AG490 reduced La protein expression and inhibited HAV IRES activities and HAV replication in African green monkey kidney GL37 cell lines. ${ }^{65}$ We also found that the JAK2 inhibitor AZD1480 inhibited the expression of phosphorylated-(Tyr-705)-signal transducer and activator of transcription 3 (STAT3) and La and inhibited HAV IRES-mediated translation and HAV replication in human hepatoma cell lines. ${ }^{15}$ Thus, La plays a role in HAV replication and might be an important target of HAV therapy. ${ }^{15,65}$
Ammonium chloride, methylamine, and dansylcadaverine also inhibit HAV protein synthesis after the attachment step. ${ }^{62}$ The effects of phospholipase A2, phospholipase C, trypsin, and beta-galactosidase on HAV infection have also been observed, and suggest that these drugs act on HAV attachment on the cellular surface. ${ }^{76}$ Monensin acts as an ionophore on intracellular vesicle compartments and may inhibit HAV infection at the uncoating step. ${ }^{77}$ Isoflavans and isoflavenes have inhibitory effects on the penetration and/or uncoating step of HAV infection. ${ }^{78}$ Cell membrane lipid components might also be attractive targets due to their interactions of HAV. ${ }^{79}$ It has previously been reported that glycyrrhizin, ${ }^{59}$ pyrazofurin, ${ }^{59}$ arabinosylcytosine, ${ }^{58}$ and carrageenan ${ }^{80}$ exhibit antiviral activities against HAV.

HAV and HCV replication were similarly sensitive to interferons, but clear differences existed for dependency on phosphatidylinositol 4-kinase III $\alpha$ and $\beta$ (PI4KIII), miR122, and immunophilins. ${ }^{14}$ HAV replication was inhibited by the "oral formulation" silibinin, a flavonolignan isolated from the milk thistle, Sylibum marianum. ${ }^{14}$ Thus, there might be many reagents that interact with $\mathrm{HAV}$ infection. Further studies are needed.

\section{Conclusions}

There are six HAV genotypes (I-VI): HAV genotypes I-III could infect humans, although only one serotype exists in HAV. Further molecular epidemiological investigations and evolutionary studies may provide a valuable opportunity to study diversified drug responses to different HAV genotypes. ${ }^{81}$ In this review, we selected the references about antiviral agents against HAV from PubMed online. DAAs and HTAs might be needed to control HAV infection. Although effective vaccines for HAV have been developed, antiviral agents against HAV should be explored until global eradication of HAV.

\section{Conflict of interest}

None

\section{Author contributions}

Drafting of the manuscript (TK), discussion and approval of the manuscript (TK, SN, SW, MN, XJ, YH, RS, OY).

\section{References}

[1] Shin SW, Kim TY, Jeong WK, Kim Y, Kim J, Kim YH, et al. Usefulness of B-mode and doppler sonography for the diagnosis of severe acute viral hepatitis $A$. J Clin Ultrasound 2014. doi: 10.1002/jcu.22234.

[2] Hayashi M, Shimizu T, Tsunematsu I, Hirokawa F, Asakuma M, Takeshita A, et al. Hepatitis A virus-related late-onset hepatic failure: a case report. Exp Clin Transplant 2011;9:150-152.

[3] Zikos D, Grewal KS, Craig K, Cheng JC, Peterson DR, Fisher KA. Nephrotic syndrome and acute renal failure associated with hepatitis $A$ virus infection. Am J Gastroenterol 1995;90:295-298.

[4] Jung YJ, Kim W, Jeong JB, Kim BG, Lee KL, Oh KH, et al. Clinical features of acute renal failure associated with hepatitis $A$ virus infection. J Viral Hepat 2010;17:611-617. doi: 10.1111/j.1365-2893.2009.01216.x.

[5] Watanabe M, Shibuya A, Okuno J, Maeda T, Tamama S, Saigenji K. Hepatitis A virus infection associated with hemophagocytic syndrome: report of two cases. Intern Med 2002;41:1188-1192. doi: 10.2169/internalmedicine. 41.1188.

[6] Lim PS, Kim IH, Kim SH, Lee SO, Kim SW. A case of severe acute hepatitis a complicated with pure red cell aplasia. Korean J Gastroenterol 2012;60: 177-181. doi: 10.4166/kjg.2012.60.3.177. 
[7] Ly KN, Klevens RM. Trends in Disease and Complications of Hepatitis A Virus Infection in the United States, 1999-2011: A New Concern for Adults. J Infect Dis 2015. doi: 10.1093/infdis/jiu834.

[8] Collier MG, Tong X, Xu F. Hepatitis A hospitalizations in the United States, 2002-2011. Hepatology 2015;61:481-485. doi: 10.1002/hep.27537.

[9] Yan J, Kanda T, Wu S, Imazeki F, Yokosuka O. Hepatitis A, B, C and E virus markers in Chinese residing in Tokyo, Japan. Hepatol Res 2012;42:974-981. doi: 10.1111/j.1872-034X.2012.01009.x.

[10] Tominaga A, Kanda T, Akiike T, Komoda H, Ito K, Abe A, et al. Hepatitis A outbreak associated with a revolving sushi bar in Chiba, Japan: Application of molecular epidemiology. Hepatol Res 2012;42:828-834. doi: 10.1111/ j.1872-034X.2012.00988.x.

[11] Wu S, Nakamoto S, Kanda T, Jiang X, Nakamura M, Miyamura T, et al. Ultradeep sequencing analysis of the hepatitis $A$ virus $5^{\prime}$-untranslated region among cases of the same outbreak from a single source. Int J Med Sci 2013;11:60-64. doi: 10.7150/ijms.7728.

[12] Kanda T, Jeong SH, Imazeki F, Fujiwara K, Yokosuka O. Analysis of $5^{\prime}$ nontranslated region of hepatitis A viral RNA genotype I from South Korea: comparison with disease severities. PLoS One 2010;5:e15139. doi: 10.1371/ journal.pone.0015139.

[13] Debing Y, Neyts J, Thibaut HJ. Molecular biology and inhibitors of hepatitis $A$ virus. Med Res Rev 2014;34:895-917. doi: 10.1002/med.21292.

[14] Esser-Nobis K, Harak C, Schult P, Kusov Y, Lohmann V. Novel perspectives for Hepatitis A Virus therapy revealed by comparative analysis of Hepatitis C Virus and Hepatitis A Virus RNA replication. Hepatology 2015. doi: 10.1002/ hep. 27847.

[15] Jiang X, Kanda T, Nakamoto S, Saito K, Nakamura M, Wu S, et al. The JAK2 inhibitor AZD1480 inhibits hepatitis A virus replication in Huh7 cells. Biochem Biophys Res Commun 2015;458:908-912. doi: 10.1016/j.bbrc.2015.02. 058.

[16] Robertson BH, Jansen RW, Khanna B, Totsuka A, Nainan OV, Siegl G, et al. Genetic relatedness of hepatitis A virus strains recovered from different geographical regions. J Gen Virol 1992;73:1365-1377.

[17] Miyamura T, Ishii K, Kanda T, Tawada A, Sekimoto T, Wu S, et al. Possible widespread presence of hepatitis A virus subgenotype IIIA in Japan: Recent trend of hepatitis A causing acute liver failure. Hepatol Res 2012;42: 248-253. doi: 10.1111/j.1872-034X.2011.00919.x.

[18] Gauss-Müller V, Kusov YY. Replication of a hepatitis A virus replicon detected by genetic recombination in vivo. J Gen Virol 2002;83:2183-2192.

[19] Konduru K, Kaplan GG. Determinants in 3Dpol modulate the rate of growth of hepatitis A virus. J Virol 2010;84:8342-8347. doi: 10.1128/JVI.01470-09.

[20] Husson RN, Shirasaka T, Butler KM, Pizzo PA, Mitsuya H. High-level resistance to zidovudine but not to zalcitabine or didanosine in human immunodeficiency virus from children receiving antiretroviral therapy. J Pediatr 1993;123:9-16.

[21] Hirotsu Y, Kanda T, Matsumura H, Moriyama M, Yokosuka O, Omata M. HCV NS5A resistance-associated variants in a group of real-world Japanese patients chronically infected with HCV genotype 1b. Hepatol Int 2015.

[22] Kanda T, Imazeki F, Yokosuka O. New antiviral therapies for chronic hepatitis C. Hepatol Int 2010;4:548-561. doi: 10.1007/s12072-010-9193-3.

[23] Zeisel MB, Lupberger J, Fofana I, Baumert TF. Host-targeting agents for prevention and treatment of chronic hepatitis $C$ - perspectives and challenges. J Hepatol 2013;58:375-384. doi: 10.1016/j.jhep.2012.09.022.

[24] Malcolm BA, Lowe C, Shechosky S, McKay RT, Yang CC, Shah VJ, et al. Peptide aldehyde inhibitors of hepatitis $A$ virus $3 \mathrm{C}$ proteinase. Biochemistry 1995;34:8172-8179.

[25] Morris TS, Frormann S, Shechosky S, Lowe C, Lall MS, Gauss-Müller V, et al. In vitro and ex vivo inhibition of hepatitis $A$ virus $3 C$ proteinase by a peptidy monofluoromethyl ketone. Bioorg Med Chem 1997;5:797-807. doi: 10.1016/ S0968-0896(97)88649-X.

[26] Huang Y, Malcolm BA, Vederas JC. Synthesis and testing of azaglutamine derivatives as inhibitors of hepatitis A virus (HAV) $3 \mathrm{C}$ proteinase. Bioorg Med Chem 1999;7:607-619. doi: 10.1016/S0968-0896(99)00006-1.

[27] Bergmann EM, Cherney MM, Mckendrick J, Frormann S, Luo C, Malcolm BA, et al. Crystal structure of an inhibitor complex of the $3 \mathrm{C}$ proteinase from hepatitis $A$ virus (HAV) and implications for the polyprotein processing in HAV. Virology 1999;265:153-163. doi: 10.1006/viro.1999.9968.

[28] Lall MS, Karvellas C, Vederas JC. Beta-lactones as a new class of cysteine proteinase inhibitors: inhibition of hepatitis $A$ virus $3 \mathrm{C}$ proteinase by N-Cbz-serine beta-lactone. Org Lett 1999;1:803-806.

[29] Ramtohul YK, James MN, Vederas JC. Synthesis and evaluation of ketoglutamine analogues as inhibitors of hepatitis A virus $3 \mathrm{C}$ proteinase. J Org Chem 2002;67:3169-3178. doi: 10.1021/jo0157831.

[30] Lall MS, Jain RP, Vederas JC. Inhibitors of 3C cysteine proteinases from Picornaviridae. Curr Top Med Chem 2004;4:1239-1253. doi: 10.2174/ 1568026043387836.

[31] Yin J, Bergmann EM, Cherney MM, Lall MS, Jain RP, Vederas JC, et al. Dual modes of modification of hepatitis $A$ virus $3 C$ protease by a serine-derived beta-lactone: selective crystallization and formation of a functional catalytic triad in the active site. J Mol Biol 2005;354:854-871. doi: 10.1016/j.jmb. 2005.09.074.

[32] Yin J, Cherney MM, Bergmann EM, Zhang J, Huitema C, Pettersson $\mathrm{H}$, et al. An episulfide cation (thiiranium ring) trapped in the active site of HAV $3 \mathrm{C}$ proteinase inactivated by peptide-based ketone inhibitors. J Mol Biol 2006; 361:673-686. doi: 10.1016/j.jmb.2006.06.047.

[33] Huitema C, Zhang J, Yin J, James MN, Vederas JC, Eltis LD. Heteroaromatic ester inhibitors of hepatitis $A$ virus $3 C$ proteinase: Evaluation of mode of action. Bioorg Med Chem 2008;16:5761-5777. doi: 10.1016/j.bmc.2008. 03.059 .

[34] Blaum BS, Wünsche W, Benie AJ, Kusov $Y$, Peters $H$, Gauss-Müller V, et al. Functional binding of hexanucleotides to $3 \mathrm{C}$ protease of hepatitis $\mathrm{A}$ virus. Nucleic Acids Res 2012;40:3042-3055. doi: 10.1093/nar/gkr1152.

[35] Funkhouser AW, Purcell RH, D'Hondt E, Emerson SU. Attenuated hepatitis A virus: genetic determinants of adaptation to growth in MRC-5 cells. J Virol 1994;68:148-157.

[36] Thang BN, Ho TB, Kanda T. A semi-supervised tensor regression model for siRNA efficacy prediction. BMC Bioinformatics 2015;16:80. doi: 10 . 1186/s12859-015-0495-2.

[37] Elbashir SM, Harborth J, Lendeckel W, Yalcin A, Weber K, Tuschl T. Duplexes of 21-nucleotide RNAs mediate RNA interference in cultured mammalian cells. Nature 2001;411:494-498. doi: 10.1038/35078107.

[38] Kanda T, Steele R, Ray R, Ray RB. Small interfering RNA targeted to hepatitis $C$ virus $5^{\prime}$ nontranslated region exerts potent antiviral effect. J Virol 2007; 81:669-676. doi: 10.1128/JVI.01496-06.

[39] Ray RB, Kanda T. Inhibition of HCV replication by small interfering RNA. Methods Mol Biol 2009;510:251-262. doi: 10.1007/978-1-59745-3943_19.

[40] Kanda T, Kusov Y, Yokosuka O, Gauss-Müller V. Interference of hepatitis A virus replication by small interfering RNAs. Biochem Biophys Res Commun 2004;318:341-345. doi: 10.1016/j.bbrc.2004.03.194.

[41] Kusov Y, Kanda T, Palmenberg A, Sgro JY, Gauss-Müller V. Silencing of hepatitis A virus infection by small interfering RNAs. J Virol 2006;80:5599-5610. doi: 10.1128/JVI.01773-05.

[42] Kanda T, Zhang B, Kusov Y, Yokosuka O, Gauss-Müller V. Suppression of hepatitis $A$ virus genome translation and replication by siRNAs targeting the internal ribosomal entry site. Biochem Biophys Res Commun 2005; 330:1217-1223. doi: 10.1016/j.bbrc.2005.03.105.

[43] Vallbracht A, Gabriel P, Zahn J, Flehmig B. Hepatitis A virus infection and the interferon system. J Infect Dis 1985;152:211-213. doi: 10.1093/infdis/152. 1.211.

[44] Kurane I, Binn LN, Bancroft WH, Ennis FA. Human lymphocyte responses to hepatitis A virus-infected cells: interferon production and lysis of infected cells. J Immunol 1985;135:2140-2144.

[45] Crance JM, Lévêque F, Chousterman S, Jouan A, Trépo C, Deloince R. Antiviral activity of recombinant interferon-alpha on hepatitis $A$ virus replication in human liver cells. Antiviral Res 1995;28:69-80. doi: 10.1016/0166-3542 (95)00039-0.

[46] Berthillon P, Crance JM, Leveque F, Jouan A, Petit MA, Deloince R, et al. Inhibition of the expression of hepatitis $A$ and $B$ viruses (HAV and HBV) proteins by interferon in a human hepatocarcinoma cell line (PLC/PRF/5). J Hepatol 1996;25:15-19.

[47] Yang L, Kiyohara T, Kanda T, Imazeki F, Fujiwara K, Gauss-Müller V, et al. Inhibitory effects on HAV IRES-mediated translation and replication by a combination of amantadine and interferon-alpha. Virol J 2010;7:212. doi: $10.1186 / 1743-422 X-7-212$.

[48] Yoshiba M, Sekiyama K, Iwamura Y, Sugata F. Development of reliable artificial liver support (ALS)-plasma exchange in combination with hemodiafiltration using high-performance membranes. Dig Dis Sci 1993;38:469-476.

[49] Yoshiba M, Inoue K, Sekiyama K. Interferon for hepatitis A. Lancet 1994; 343:288-289. doi: 10.1016/S0140-6736(94)91132-0.

[50] Sánchez-Tapias JM, Mas A, Costa ], Bruguera M, Mayor A, Ballesta AM, et al. Recombinant alpha 2c-interferon therapy in fulminant viral hepatitis. J Hepatol 1987;5:205-210.

[51] Levin S, Leibowitz E, Torten J, Hahn T. Interferon treatment in acute progressive and fulminant hepatitis. Isr J Med Sci 1989;25:364-372.

[52] Maier K, Gabriel P, Koscielniak E, Stierhof YD, Wiedmann KH, Flehmig B, et al. Human gamma interferon production by cytotoxic $T$ lymphocytes sensitized during hepatitis A virus infection. J Virol 1988;62:3756-3763. doi: 0022538X/88/103756-08.

[53] Kanda T, Wu S, Kiyohara T, Nakamoto S, Jiang X, Miyamura T, et al. Interleukin-29 suppresses hepatitis $A$ and $C$ viral internal ribosomal entry site-mediated translation. Viral Immunol 2012;25:379-386. doi: 10.1089/ vim.2012.0021.

[54] Li O, Kawamura K, Ma G, Iwata F, Numasaki M, Suzuki N, et al. Interferonlambda induces $\mathrm{G} 1$ phase arrest or apoptosis in oesophageal carcinoma cells and produces anti-tumour effects in combination with anti-cancer agents. Eur J Cancer 2010;46:180-190. doi: 10.1016/j.ejca.2009.10.002. 
[55] Katz $E$, Margalith $E$, Winer $B$. Inhibition of vaccinia virus growth by the nucleoside analogue 1-beta-D-ribofuranosyl-1,2,4-triazole-3-carboxamide (virazole, ribavirin). J Gen Virol 1976;32:327-330.

[56] Kakumu S, Yoshioka K, Wakita T, Ishikawa T, Takayanagi M, Higashi Y. A pilot study of ribavirin and interferon beta for the treatment of chronic hepatitis $\mathrm{C}$. Gastroenterology 1993;105:507-512.

[57] Kanda T, Yokosuka O, Imazeki F, Tanaka M, Shino Y, Shimada H, et al. Inhibition of subgenomic hepatitis $C$ virus RNA in Huh-7 cells: ribavirin induces mutagenesis in HCV RNA. J Viral Hepat 2004;11:479-487.

[58] Widell A, Hansson BG, Oberg B, Nordenfelt E. Influence of twenty potentially antiviral substances on in vitro multiplication of hepatitis A virus. Antiviral Res 1986;6:103-112.

[59] Crance JM, Biziagos E, Passagot J, van Cuyck-Gandré H, Deloince R. Inhibition of hepatitis A virus replication in vitro by antiviral compounds. J Med Virol 1990;31:155-160.

[60] Chaudhary RK, Andonov AP. Effect of ribavirin on hepatitis A virus replication in vitro. Can J Infect Dis 1992;3:67-70.

[61] Kanda T, Yokosuka O, Imazeki F, Fujiwara K, Nagao K, Saisho H. Amantadine inhibits hepatitis A virus internal ribosomal entry site-mediated translation in human hepatoma cells. Biochem Biophys Res Commun 2005;331:621-629. doi: $10.1016 / j$.bbrc. 2005.03.212.

[62] Superti F, Seganti L, Orsi N, Divizia M, Gabrieli R, Panà A. The effect of lipophilic amines on the growth of hepatitis A virus in Frp/3 cells. Arch Virol 1987;96:289-296.

[63] Kanda T, Imazeki F, Nakamoto S, Okitsu K, Fujiwara K, Yokosuka O. Internal ribosomal entry-site activities of clinical isolate-derived hepatitis A virus and inhibitory effects of amantadine. Hepatol Res 2010;40:415-423. doi: 10. 1111/j.1872-034X.2010.00617.x.

[64] Debing Y, Kaplan GG, Neyts J, Jochmans D. Rapid and convenient assays to assess potential inhibitory activity on in vitro hepatitis A replication. Antiviral Res 2013;98:325-331. doi: 10.1016/j.antiviral.2013.03.016.

[65] Jiang X, Kanda T, Wu S, Nakamoto S, Saito K, Shirasawa H, et al. Suppression of La antigen exerts potential antiviral effects against hepatitis A virus. PLoS One 2014;9:e101993. doi: 10.1371/journal.pone.0101993.

[66] Cordes S, Kusov Y, Heise T, Gauss-Müller V. La autoantigen suppresses IRESdependent translation of the hepatitis A virus. Biochem Biophys Res Commun 2008;368:1014-1019. doi: 10.1016/j.bbrc.2008.01.163.

[67] Schultz DE, Hardin CC, Lemon SM. Specific interaction of glyceraldehyde 3-phosphate dehydrogenase with the $5^{\prime}$-nontranslated RNA of hepatitis A virus. J Biol Chem 1996;271:14134-14142. doi: 10.1074/jbc.271.24.14134.

[68] Yi M, Schultz DE, Lemon SM. Functional significance of the interaction of hepatitis A virus RNA with glyceraldehyde 3-phosphate dehydrogenase (GAPDH): opposing effects of GAPDH and polypyrimidine tract binding protein on internal ribosome entry site function. J Virol 2000;74:64596468. doi: $10.1128 /$ JVI.74.14.6459-6468.
[69] Venkatramana M, Ray PS, Chadda A, Das S. A 25 kDa cleavage product of polypyrimidine tract binding protein (PTB) present in mouse tissues prevents PTB binding to the $5^{\prime}$ untranslated region and inhibits translation of hepatitis A virus RNA. Virus Res 2003;98:141-149. doi: 10.1016/j.virusres.2003.09. 004.

[70] Kanda T, Gauss-Müller V, Cordes S, Tamura R, Okitsu K, Shuang W, et al. Hepatitis A virus (HAV) proteinase $3 \mathrm{C}$ inhibits HAV IRES-dependent translation and cleaves the polypyrimidine tract-binding protein. J Viral Hepat 2010;17:618-623. doi: 10.1111/j.1365-2893.2009.01221.x.

[71] Graff J, Cha J, Blyn LB, Ehrenfeld E. Interaction of poly $(\mathrm{rC})$ binding protein 2 with the $5^{\prime}$ noncoding region of hepatitis A virus RNA and its effects on translation. J Virol 1998;72:9668-9675.

[72] Zhang B, Morace G, Gauss-Müller V, Kusov Y. Poly(A) binding protein, C-terminally truncated by the hepatitis $A$ virus proteinase $3 C$, inhibits viral translation. Nucleic Acids Res 2007;35:5975-5984. doi: 10.1093/nar/ gkm645.

[73] Ali IK, McKendrick L, Morley SJ, Jackson RJ. Activity of the hepatitis A virus IRES requires association between the cap-binding translation initiation factor (eIF4E) and eIF4G. J Virol 2001;75:7854-7863. doi: 10.1128/JVI. 75.17.7854-7863.2001.

[74] Borman AM, Kean KM. Intact eukaryotic initiation factor $4 G$ is required for hepatitis A virus internal initiation of translation. Virology 1997;237: 129-136. doi: 10.1006/viro.1997.8761.

[75] Redondo N, Sanz MA, Steinberger J, Skern T, Kusov Y, Carrasco L. Translation directed by hepatitis A virus IRES in the absence of active eIF4F complex and eIF2. PLoS One 2012;7:e52065. doi: 10.1371/journal.pone.0052065.

[76] Seganti L, Superti F, Orsi N, Gabrieli R, Divizia M, Panà A. Study of the chemical nature of Frp/3 cell recognition units for hepatitis A virus. Med Microbiol Immunol 1987;176:21-26.

[77] Superti F, Seganti L, Orsi N, Divizia M, Gabrieli R, Panà A. Effect of cellular function inhibitors on the infection of Frp/3 cells by hepatitis $A$ virus. Med Microbiol Immunol 1989;178:29-36.

[78] Superti F, Seganti L, Orsi N, Divizia M, Gabrieli R, Panà A, et al. Effect of isoflavans and isoflavenes on the infection of $\mathrm{Frp} / 3$ cells by hepatitis $A$ virus. Antiviral Res 1989;11:247-254.

[79] Seganti L, Superti F, Orsi N, Gabrieli R, Divizia M, Panà A. Membrane lipid components interacting with hepatitis A virus. Microbiologica 1989;12: 225-230.

[80] Girond S, Crance JM, Van Cuyck-Gandre H, Renaudet J, Deloince R. Antiviral activity of carrageenan on hepatitis A virus replication in cell culture. Res Virol 1991;142:261-270.

[81] Costa-Mattioli M, Di Napoli A, Ferré V, Billaudel S, Perez-Bercoff R, Cristina J. Genetic variability of hepatitis A virus. J Gen Virol 2003;84:3191-3201. doi: $10.1099 /$ vir. 0.19532-0. 